\title{
CONCENTRATION AND SIZE OF AIRBORNE PARTICLES IN MANUFACTURING ENVIRONMENTS ${ }^{1}$
}

Renilson Luiz Teixeira ${ }^{2}$, Raphael Nogueira Rezende ${ }^{3 *}$, José Reinaldo Moreira da Silva ${ }^{4}$ and Luana Elís de Ramos e Paula ${ }^{5}$

\footnotetext{
${ }^{1}$ Received on 19.09.2017 accepted for publication on 01.02.2018.

${ }^{2}$ Instituto Federal de Educação, Ciência e Tecnologia do Espírito Santo, Campus Colatina, Colatina, ES - Brail. E-mail: $<$ renilson@ifes.edu.br>.

${ }^{3}$ Instituto Federal de Educação, Ciência e Tecnologia do Sul de Minas Gerais, Campus Muzambinho, Muzambinho, MG Brasil. E-mail: <raphael.rezende@ifsuldeminas.edu.br>.

${ }^{4}$ Universidade Federal de Lavras, Departamento de Ciências Florestais, Lavras, MG - Brasil. E-mail: <josereinaldo@dcf.ufla.br>.

${ }^{5}$ Universidade Federal de Lavras, Departamento de Engenharia, Lavras, MG - Brasil. E-mail: <luana.paula@deg.ufla.br>.

*Corresponding author.
}

\begin{abstract}
In furniture factories, the cutting of medium density fiberboard (MDF) generates high concentrations of particulates suspended in the air, which, depending on their dimensions, can reach the sensitive areas of the respiratory tract of workers. The aim of this study was to test a method to measure particle sizes derived from the cutting of wood paneling. The experiment was conducted in two small furniture factories located in the municipality of Lavras, Minas Gerais state, Brazil. During the cutting of MDF, airborne particles were collected and measured by means of optical microscopy. The data obtained showed a critical condition in the work environments, with high concentrations of small particles ( $<10$ microns $)$, which could be lodged in the workers' lungs. The particle measuring process proved to be accurate and easy to perform. In addition, it is worth noting the importance of investment in personal protective equipment (PPE) such as hoods and/ or PFF2 dust masks for the protection of workers.
\end{abstract}

Keywords: Work Safety; Occupational Hygiene; Furniture Factories.

\section{CONCENTRAÇÃO E DIMENSÕES DE PARTICULADOS SUSPENSOS NO AR DE AMBIENTES FABRIS}

\begin{abstract}
RESUMO-Em fábricas de móveis, o corte de painéis de fibras de média densidade (MDF) gera altas concentrações de particulados suspensos no ar, que dependendo de suas dimensões podem atingir áreas sensíveis do aparelho respiratório dos trabalhadores. O objetivo desse trabalho foi testar um método para medir dimensões de partículas oriundas do corte de painéis de madeira. O experimento foi desenvolvido em duas fábricas de móveis, de pequeno porte, em Lavras/MG. Durante o corte de painéis MDF foram coletadas e medidas partículas suspensas no ar, por meio de microscopia óptica. Os dados obtidos mostraram uma condição crítica no ambiente de trabalho, com elevadas concentrações de partículas pequenas $(<10 \mu \mathrm{m})$, que podem se alojar nos pulmões dos trabalhadores. O processo de medição das partículas demonstrou-se preciso e de fácil execução. Também, observou a importância de investimentos em exaustores (EPC) e, ou respirador tipo PFF2 (EPI), para a proteção dos trabalhadores.
\end{abstract}

Palavras-Chave: Segurança do Trabalho; Higiene Ocupacional; Fábricas de Móveis. 


\section{INTRODUCTION}

Currently, most wood furniture factories have no control over the emission of wood particles suspended in air. Locations with high concentrations of these agents generate discomfort and can cause dermatitis, irritation, respiratory allergies and obstructions, asthma, cardiovascular conditions, and cancer (American Conference of Governmental Industrial Hygienists, 2008; Jesus et al., 2012; Oliveira et al., 2014; Saliba, 2013).

During the processing of wood, carpenters and sawmill workers are exposed to different risk agents, such as dust, fibers, particle wastes containing adhesives, and high levels of monoterpenes (Edman et al., 2003; Hagstrom et al., 2008; Nunes and Moreschi, 2009a; Svedberg et al., 2004). Workers in industries of agglomerate material, for instance, are also exposed to chemical risks, such as resin acids, which cause absenteeism, chronic health effects, and various respiratory problems (Gomes-Yepes and Cremades, 2010; Hagström et al., 2008; Keira et al., 1997; Sadhra et al., 1994).

The efficiency with which inhaled particles are deposited in the human respiratory tract depends on their size, shape, density, and hygroscopicity. Particles small enough to be suspended in air can be inhaled through the nose or mouth, and the probability of inhaling them depends on their size, the movement of air around the respiratory tract, and the respiration rate of individuals (Santos, 2005).

The path of particles in the different regions of the respiratory tract and the places they are likely to be lodged are dependent on their size, airway dimensions, and respiratory pattern. Particles deposited in the upper airways or lungs have the potential to cause various health damages (Santos, 2005).

Considering the great interest of occupational hygiene in the classification of airborne particulate dimensions, field studies have become increasingly relevant, because particle size may be associated with the site of deposition in the respiratory tract and damage to health.

In this context, the objective of this study was to test a method to measure particle size by means of optical microscopy based on the concentration of airborne dust resulting from the cutting of medium density fiberboard (MDF).

Revista Árvore. 2018;42(1):e420108

\section{MATERIALAND METHODS}

The experiment was conducted in the medium density fiberboard (MDF) cutting sector of two wood furniture factories, labeled 1 and 2, located in the municipality of Lavras, Minas Gerais state, Brazil.

The procedures defined by the Occupational Hygiene Standards NHO 03 (Fundação Jorge Duprat e Figueiredo, 2001) and NHO 08 (Fundação Jorge Duprat e Figueiredo, 2009) were followed for collection of suspended dust, Test Method for Gravimetric Analysis of Solid Aerodispersoids on Membrane Filters and Technical Procedure for Collecting Solid Particle Material Suspended in Air from Working Environments, respectively. In order to complement this type of evaluation, technical parameters defined by the National Institute for Occupational Safety and Health - NIOSH were used according to the Manual of Analytical Methods no. 0500 - Particulates Not Otherwise Regulated, Total (National Institute for Occupational Safety and Health, 1994).

Optical methodology was used to assess the dimensions of the collected particles. The particulate matter retained on the PVC membrane filters was collected and deposited on glass slides. A drop of glycerin was added to the slides, which were covered with coverslips and analyzed under an optical microscope coupled to the Wincel-Pro-Plus image analysis system. The magnification used in all measurements was $400 \mathrm{X}$.

Particle-size analysis was performed considering a completely randomized design with two treatments (with and without exhaustion). The number of repetitions was four and three for systems with and without exhaustion, respectively. The systems with and without exhaustion for factories 1 and 2 were compared using the Kruskal-Wallis non-parametric test with subsequent application of the Student's t-test at 5\% significance level. Four replicates were used for factory 1 (system with exhaustion), whereas seven replicates were used for factory 2 (system without exhaustion). The factories were also compared considering only the system without exhaustion, with three and seven repetitions, respectively. The Kruskal-Wallis test followed by the Student's ttest were applied at 5\% significance level.

\section{RESULTS}

The minimum, mean and maximum values of the airborne dust particles according to concentration level, 
as well as the standard deviations and coefficients of variation, collected at factory 1 during the cutting of medium density fiberboard (MDF), with and without exhaustion, using circular saw are presented in Table 1.

Table 2 shows the minimum, mean and maximum values of the airborne dust particles according to concentration level, as well as the standard deviations and coefficients of variation collected at factory 2 during the cutting of MDFusing sectioning machine.

The overall respirable, thoracic, inhalable and noninhalable particulate matter of airborne dust during MDF cutting at factories 1 and 2 are shown in Table 3 .

Figure 1 shows the multiple comparisons of the mean dimensions of the airborne particles collected at factory 1 with and without exhaust system.

The comparison between the concentration and dimensions of the airborne particles collected at factories 1 (circular saw) and 2 (sectioning machine) with exhaust system is presented in Figure 2.

\section{DISCUSSION}

At factory 1, no increasing or decreasing trend between the concentration and the particle size of airborne dust (Table 1) was observed, and great variation in particle size due to the high coefficients of variation was found. It is worth mentioning that variation in concentration is high in wood processing environments, which according to Oliveira et al. (2014), can reach up to six times the threshold limit defined by the American Conference of Governmental Industrial
Hygienists (2017), and more than 130 times that in places without exhaustion, according to the results of Teixeira et al. (2017).

At factory 2,no increasing or decreasing trend between the concentration and the size of airborne dust particles (Table 2) was also observed, and great variation in particle size due to the high coefficients of variation was also found. Thus, cutting performed in sectioning machines did not change the quality of particles compared with that from circular saws. However, presence of smaller particles was observed, which increases the risk of lung diseases according to the study by Jesus et al. (2012), which demonstrates that finer particles, generally $<10 \mu \mathrm{m}$, penetrate more deeply in the respiratory system, and are of greater risk to workers'health.

In general, the mean concentrations obtained atfactories 1 and 2 were higher than those reported by Nunes and Moreschi (2009a) and Oliveira et al. (2014), who found variation from 2.0 to $16.0 \mathrm{mg} . \mathrm{m}^{-3}$. The same was observed for the dimensions, whose means ranged from 11 to $55 \mu \mathrm{m}$, differing from the values obtained by Nunes and Moreschi (2009b) for agglomerate particles, with means between 3.5 and $6.5 \mu \mathrm{m}$, possibly because of variations in processing, machinery, and processed material.

In the analyzed factories, presence of particulate matter harmful to humans was observed even in small concentrations, below the threshold limit values established by the American Conference of Governmental Industrial Hygienists (2017), corresponding to the range of respirable particulates (Table 3). This finding is consistent with the observations of Nunes and Moreschi (2009a), who

Table 1 - Minimum, mean and maximum values, standard deviation of the mean, and coefficient of variation of the dust particles suspended in the air at factory 1 , with and without exhaustion system.

Tabela 1 - Valores mínimos, médios, máximos, desvio padrão da media, e coeficiente de variação das partículas de poeiras suspensas no ar, por nivel de concentração na empresa 1, com e sem exaustão.

\begin{tabular}{|c|c|c|c|c|c|c|c|}
\hline \multirow[t]{3}{*}{ Parameters } & \multicolumn{6}{|c|}{ Dimensions of dust particles (ìm) } & \\
\hline & \multicolumn{3}{|c|}{ Samples withexhaustion } & & \multicolumn{3}{|c|}{ Samples without exhaustion } \\
\hline & 1 & 2 & 3 & 4 & 5 & 6 & 7 \\
\hline Concentration $\left(\mathrm{mg} \cdot \mathrm{m}^{-3}\right)$ & 15.24 & 33.95 & 43.65 & 48.90 & 40.65 & 66.69 & 68.59 \\
\hline Minimum & 12.60 & 1.74 & 6.79 & 5.43 & 1.83 & 4.86 & 3.88 \\
\hline Mean & 54.97 & 17.33 & 36.51 & 41.12 & 14.20 & 37.41 & 34.15 \\
\hline Maximum & 237.31 & 187.38 & 137.78 & 195.94 & 64.50 & 158.52 & 160.86 \\
\hline $\begin{array}{l}\text { Standard deviation of } \\
\text { the mean }(\mu \mathrm{m})\end{array}$ & 45.69 & 27.96 & 21.47 & 37.06 & 12.92 & 29.08 & 24.96 \\
\hline $\begin{array}{l}\text { Coefficient of } \\
\text { variation }(\%)\end{array}$ & 120 & 62 & 170 & 111 & 110 & 129 & 137 \\
\hline
\end{tabular}


Table 2 - Minimum, mean and maximum values, standard deviation of the mean, and coefficient of variation of the dust particles suspended in the air at factory 2 with exhaustion system.

Tabela 2 - Valores mínimos, médios, máximos, desvio padrão da média, e coeficiente de variação das partículas de poeiras suspensas no ar, por nível de concentração na empresa 2, com exaustão.

\begin{tabular}{|c|c|c|c|c|c|c|c|}
\hline \multirow[t]{2}{*}{ Parameters } & \multicolumn{7}{|c|}{$\begin{array}{l}\text { Dimensions of dust particles (ìm) } \\
\text { Samples with exhaustion }\end{array}$} \\
\hline & 1 & 2 & 3 & 4 & 5 & 6 & 7 \\
\hline $\begin{array}{l}\text { Concentration } \\
\left(\mathrm{mg} \cdot \mathrm{m}^{-3}\right)\end{array}$ & 0.00 & 1.72 & 1.77 & 1.77 & 2.66 & 3.55 & 8.87 \\
\hline Minimum & 1.84 & 3.76 & 2.05 & 3.49 & 2.33 & 4.68 & 2.68 \\
\hline Mean & 12.13 & 17.46 & 12.12 & 11.46 & 20.60 & 18.28 & 17.07 \\
\hline Maximum & 38.52 & 49.65 & 62.36 & 28.40 & 40.77 & 70.78 & 49.25 \\
\hline $\begin{array}{l}\text { Standard deviation } \\
\text { of the mean (ìm) }\end{array}$ & 9.63 & 10.62 & 11.83 & 7.01 & 9.90 & 11.96 & 11.20 \\
\hline $\begin{array}{l}\text { Coefficient of } \\
\text { variation }(\%)\end{array}$ & 126 & 164 & 102 & 163 & 208 & 153 & 152 \\
\hline
\end{tabular}

Table 3 - Maximum and minimum values of the size of respirable, thoracic, inhalable and non-inhalable particulate matter of airborne dust during MDF cutting in factories 1 and 2.

Tabela 3 - Valores das dimensões mínimas e máximas das partículas respirável, torácica, inalável e não inalável das poeiras suspensas no ar durante o corte do MDF nas empresas 1 e 2.

\begin{tabular}{|c|c|c|c|}
\hline \multirow{2}{*}{ Types and sizesof particles } & \multicolumn{2}{|c|}{ Factory 1* } & \multirow[t]{2}{*}{ Factory $2 * *$} \\
\hline & Withexhaustion & Without exhaustion & \\
\hline Respirable $<10 \mu \mathrm{m}$ & 1.74 to 9.86 & 1.83 to 9.92 & 1.84 to 9.89 \\
\hline Thoracic $<25 \mu \mathrm{m}$ & 10.24 to 24.89 & 10.17 to 24.95 & 10.19 to 24.99 \\
\hline Inhalable $<100 \mu \mathrm{m}$ & 25.06 to 96.85 & 25.00 to 99.84 & 25.01 to 70.78 \\
\hline Non-inhalable $>100 \mu \mathrm{m}$ & 110.80 to 237.31 & 117.77 to 160.86 & - \\
\hline
\end{tabular}

Circular saw; ** Sectioning machine with exhaustion.

consider potential occupational risk for workers exposed to respirable particulate from wood panels.

In addition, a large distribution of particle size was observed regardless of particle concentrations in the environment. These facts corroborate the findings by several authors such as Harper et al. (2004), Hinds (1988), Pisaniello et al. (1991), Tatum et al. (2001), Verma et al. (2007), and Whitehead et al. (1981), who reported that particles $<10 \mu \mathrm{m}$ are present even at small concentrations of airborne particulates. It is important to note that the smaller the particles, the greater the discomfort, insecurity, and the possibility of reaching the bronchi, putting workers at greater risk of respiratory diseases.

Fiedler et al. (2010), in a study on the work environment of carpenters using solid wood and medium density fiberboard (MDF), found that more than $60 \%$ of the workers considered the presence of excessive dust and $15 \%$ of them felt uncomfortable with dust because it causes respiratory problems.
According to Oliveira et al. (2014), particles $<10$ ìm remain suspended in the air even in environments with exhaust systems. Thus, they can be inhaled by workers and reduce the respiration rate, according to Mohan et al. (2013). However, the presence of an exhaust system enables improvement of comfort, safety, and cleanliness in the workplace.

Figure 1 shows that there was no statistically significant difference, by the $\mathrm{F}$ test at $5 \%$ significance level, between the mean dimensions of the airborne particles in environments with and without exhaustion system. This fact, once again, confirms that, regardless of concentration level, there is a wide distribution of particle size, which is evidenced by the high standard deviation values found in the different collections.

Figure 2 shows that there was statistically significant difference, by the Student's $t$-test at $5 \%$ significance level, between the mean dimensions of the airborne particles with exhaustion system at factories 1 and 2 .

Revista Árvore. 2018;42(1):e420108 


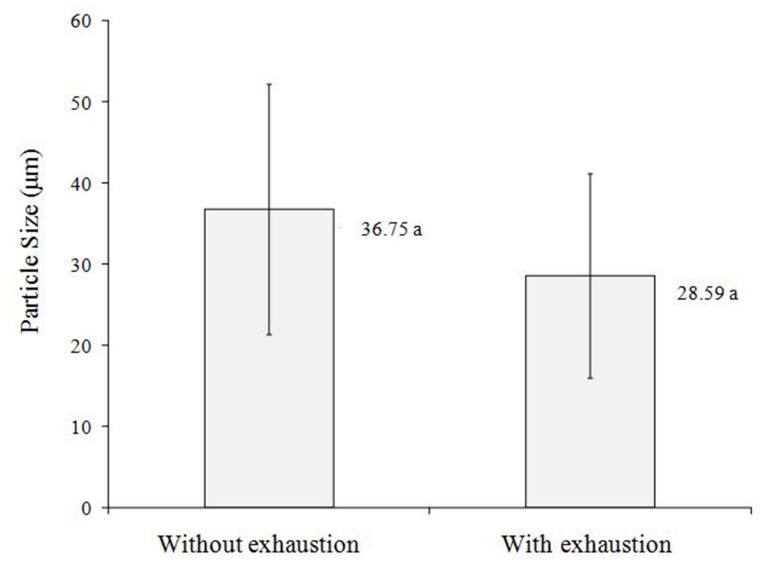

Figure 1 - Multiple comparisons of mean dimensions of the airborne particles, with and without exhaustion system, at factory 1 . Means followed by the same letter do not significantly differ at $5 \%$ significance level by the F-test.

Figura 1 - Comparação múltipla das médias das concentrações de particulados suspenso no ar, com e sem sistema de exaustão, na empresa 1. Médias seguidas pela mesma letra não diferem entre si a $5 \%$ pelo teste $F$.

The most likely explanation is that sectioning machines have exhaust systems better sized for their respective characteristics. Therefore, in this type of processing, the particle suction system removes the larger particles from the environment. However, smaller particles are easier to be dispersed in air, hindering their removal by suction. This fact can be verified in the reduced standard deviation values of the means of the particle dimensions observed in the different factories. It can be observed that, at factory 2 , the standard deviation of the mean was reduced by $70 \%$, compared with that of factory 1 .

The presence of particles $<10 \mu \mathrm{m}$ in these environments shows the need to establish special occupational care regulations. Even in the presence of exhaust systems, Brasil (1978), Mohan et al. (2013), and Nunes and Moreschi (2009b) reinforce the need for continuous monitoring, periodic medical examinations, eye protection, and the use of appropriate respirators with filters to protect against fine particles, fumes, and toxic mists (PFF2).

The particles sampled were sections of wood fibers of varying shapes- from long sections of wood fiber adhered to residues, probably from the adhesive used in the manufacturing of MDF panels, to rounded

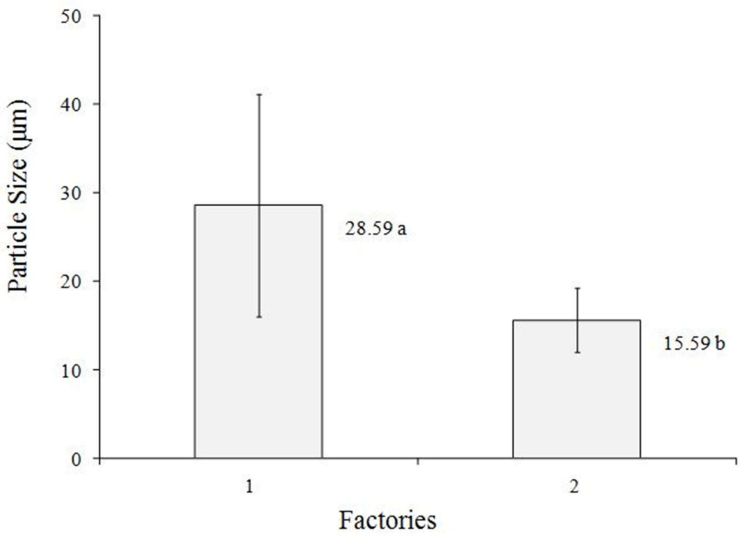

Figure 2 - Multiple comparisons of the mean dimensions of the airborne particles, with exhaustion system, at factories 1 and 2. Means followed by the same letter do not significantly differ at $5 \%$ significance level by the Student's $t$-test.

Figura 2 - Comparação múltipla das médias das dimensões de particulados suspenso no ar, com sistema de exaustão, nas empresas 1 e 2. Médias seguidas pela mesma letra não diferem entre si a $5 \%$ pelo teste $t$-Student.

particulates with adhesive and crystals present on the MDF, corroborating the observations by Nunes and Moreschi (2009a). In future works, the use of special dyes applied to the residues can facilitate the identification and even the composition of particles.

\section{CONCLUSION}

Based on the results presented in this study, we conclude that the distribution of particles suspended in air showed a widely variable profile regardless of the concentrations present in the manufacturing environments; the process of measuring the particles by means of optical microscopy has proved to be precise as a function of the values obtained; the quality of the air in these factories during the cutting of MDF may represent a health risk to workers; even when exhaust systems are used, suitable masks or respirators with filters, both intended to protect against fine particles, smoke, and toxic mists (PFF2), must be worn by workers.

\section{ACKNOWLEDGMENTS}

The authors are grateful to the Federal Institute of Education, Science and Technology of the South of Minas Gerais - IFSULDEMINAS and the Federal 
Institute of Education, Science and Technology of Espírito Santo - IFES for the support granted.

\section{REFERENCES}

American Conference of Governmental Industrial Hygienists. TLVs and BEIs: handbook. Cincinnati: ACGIH; 2008. 256 p.

American Conference of Governmental Industrial Hygienists. TLVs and BEIs: handbook. Cincinnati: ACGIH; 2017.288 p.

Brasil. Ministério do Trabalho e Emprego. Portaria $\mathrm{n}^{\circ} 3.214$ de 8 de junho de 1978 e atualizações. Norma Regulamentadora $n^{\circ} 6$ - NR 6: equipamento de proteção individual - EPI. Diário Oficial da União, Brasília, 6 de julho de 1978.8 p.

Edman K, Lofstedt H, Berg P, Eriksson K, Axelsson S, Bryngelsson I, et al. Exposure assessment to alpha- and beta-pinene, deltacarene and wood dust in industrial production of wood pellets. Ann Occup Hyg. 2003 Apr;47(3):219-26. PMid:12639835.

Fiedler NC et al. Avaliação ergonômica do ambiente de trabalho em marcenarias no sul do Espírito Santo. Árvore. 2010; 34(5): 907-915. http:/ /dx.doi.org/10.1590/S0100-67622010000500016.

Fundação Jorge Duprat e Figueiredo. Ministério do Trabalho e Emprego. Norma de Higiene Ocupacional 03: método de ensaio: análise gravimétrica de aerodispersóides sólidos sobre filtros de membrana. São Paulo: Fundacentro, MTE; 2001.

Fundação Jorge Duprat e Figueiredo. Ministério do Trabalho e Emprego. Norma de Higiene Ocupacional 08: procedimento Técnico: coleta de material particulado sólido suspenso no ar de ambientes de trabalho. São Paulo: Fundacentro, MTE; 2009.

Gomes-Yepes ME, Cremades LV. Análisis de la incidencia de patologías respiratorias por exposición al polvo de madera en los carpinteros del Quindío (Colombia). Cienc Trab. 2010;12(38):433-9.

Hagström K, Axelsson S, Arvidsson H, Bryngelsson IL, Lundholm C, Eriksson K.
Exposure to wood dust, resin acids and volatile organic compounds during production of wood pellets. J Occup Environ Hyg. 2008;5(5):296-304. http://dx.doi.org/10.1080/15459620801957225. PMid:18322870.

Harper M, Akbar MZ, Andrew ME. Comparison of wood-dust aerosol size-distributions collected by air samplers. J Environ Monit. 2004;6(1):18-22. http://dx.doi.org/10.1039/b312883k. PMid:14737465.

Hinds WC. Basis for particle size-selective sampling for wood dust. Appl Ind Hyg. 1988;3(3):67-72. http://dx.doi.org/10.1080/ 08828032.1988 .10389273 .

Jesus L, Andrade I, Pocinho M, Girão A. Exposição ocupacional ao formaldeído, COV e partículas: impacto na saúde humana. Interações. 2012;22:77-93.

Keira T, Aizawa Y, Karube H, Niituya M, Shinohara S, Kuwashima A, et al. Adverse effects of colophony. Ind Health. 1997;35(1):1-7. http:// dx.doi.org/10.2486/indhealth.35.1. PMid:9009495.

Mohan M, Aprajita, Panwar NK. Effect of wood dust on respiratory health status of carpenters. J Clin Diagn Res. 2013;7(8):1589-91. PMid:24086847.

National Institute for Occupational Safety and Health. Manual of analytical methods no. 0500: particulates not oherwise regulated total. Washington: NIOSH; 1994 [cited 2010 Aug 6]. Available from: http://www.cdc.gov/niosh/docs/ 2003-154/pdfs/0500.pdf

Nunes ELS, Moreschi JC. Análise dos aerodipsrsóides sólidos produzidos na industrialização da madeira. Floresta. 2009a;39(4):765-72. http://dx.doi.org/10.5380/ rf.v39i4.16311.

Nunes ELS, Moreschi JC. Comportamento aerodinâmico do aerodispersóide sólido resultante do processamento mecânico de paineis de madeira aglomerada. In: Anais do XXIX Encontro Nacional de Engenharia de Produção; 2009; Salvador, BA, Brasil. Rio de Janeiro: ABEPRO; 2009b. p. 1-13.

Oliveira E Jr, Almeida FSS, Morrone LC. Avaliação de riscos de uma empresa de embalagens de madeira. Laborativa. 2014;3(2):41-55.

Revista Árvore. 2018;42(1):e420108 
Pisaniello DL, Connell KE, Muriale L. Wood dust exposure during furniture manufacture: results from an Australian survey and considerations for threshold limit value development. Am Ind Hyg Assoc J. 1991;52(11):485-92. http://dx.doi.org/ 10.1080/15298669191365090. PMid:1746411.

Sadhra S, Foulds IS, Gray CN, Koh D, Gardiner K. Colophony-uses, health effects, airborne measurement and analysis. Ann Occup Hyg. 1994;38(4):385-96. PMid:7978961.

Saliba TM. Manual prático de higiene ocupacional e PPRA. São Paulo: LTr; 2013. 367 p.

Santos AMA. Exposição ocupacional a poeiras em marmorarias: tamanhos de partículas

característicos [tese]. Belo Horizonte:

Universidade Federal de Minas Gerais; 2005.

Svedberg UR, Högberg HE, Högberg J, Galle B. Emission of hexanal and carbon monoxide from storage of wood pellets, a potential occupational and domestic health hazard. Ann Occup Hyg. 2004 Jun;48(4):339-49. PMid:15191943.
Tatum VL, Ray AE, Rovell-Rixx DC. The performance of personal inhalable dust sampler in wood-products industry facilities. Appl Occup Environ Hyg. 2001;16(7):763-9. http://dx.doi.org/ 10.1080/10473220121612. PMid:11458924.

Teixeira RL, Silva JRM, Fiedler NC, Lima JT, Trugilho PF, Neri AC. Evaluation of airborne MDF dust concentration in furniture factories. Floram. 2017;24(0):1-6. http://dx.doi.org/10.1590/21798087.086514 .

Verma DK, et al. Occupational exposure to chemical, biological, and physical agents in Ontario sawmill and veneer/plywood plants. Ontario: OFSWA; 2007 [cited 2007 Aug 10]. Available from: http://www.ofswa.on.ca/ downloads/downloads.asp

Whitehead LW, Freund T, Hahn L. Suspended dust concentrations and size distributions, and qualitative analysis of inorganic particles, from woodworking operations. Am Ind Hyg Assoc J. 1981;42(6):461-7. http://dx.doi.org/10.1080/ 15298668191420062 . 